\title{
Study Guides - Perceptions of Medical Students
}

\author{
Muhammad Suleman Sadiq Hashmi ${ }^{*}$ and Afifa Tabassum ${ }^{1}$ \\ ${ }^{1}$ Department of Health Professions Education, Liaquat National Hospital, Karachi, Pakistan
}

\begin{abstract}
:
Background: A study guide is a document that is designed to assist students with learning. It not only defines the "what" but also the "how" and "how much" of learning for a student. A well designed study guide can be valuable in not only supporting but also in promoting self-learning. A lot of effort and resources go into the preparation and production of a study guide. Very few studies are available that address the perception of students about the usefulness of study guides in the local context.
\end{abstract}

Objective: To assess the perceived usefulness of study guide in undergraduate medical students.

Methods: The cross-sectional study was conducted at Liaquat National Medical College. Survey population comprised of second year medical students. A survey form with closed ended statements was administered to participants. Data was analyzed on SPSS 18.

Results: A total of 100 forms were distributed out of which 89 forms were returned. Only 80 forms were completely filled (response rate $80 \%$ ). About $68(47.5 \%$ ) of the students found the study guide easy to follow. $54(67.6 \%)$ students found the study guide helpful in realizing the importance of the module being conducted. About $38(47.6 \%)$ of students agreed to the usefulness of learning resources mentioned. About $68(85 \%)$ of students agreed that exam rules were clearly stated and almost $49(61.3 \%)$ felt that information on assessment tools was useful in preparing for the exams. Only 31(38.8\%) of students believed that study guide supported learning.

Conclusion: Study guides are an important component of the curriculum. Our study supports usefulness of study guide in areas like importance of module, learning objectives, strategies and assessment but some improvements can be made as identified by this study. Furthermore, awareness needs to be created among students on the proper use of study guides.

Keywords: Study guides, Perception, Medical undergraduates.

\section{INTRODUCTION}

The major challenge that students of developing countries face when they enter medical college is a transition from teacher centered methods to student centered methods of study. The students have been mostly exposed to a teacher centered, specified and fixed curriculum during secondary school. The change in study methods in medical college poses a challenge for most students. To ensure satisfactory learning students should be provided guidance and resources to help them develop their learning skills [1].

Study guide is defined as "an aid, usually in the form of printed notes, designed to assist students with their learning. It indicates what should be learned, how it can be learned, and how students can recognize if they have learned it" [2]. A well designed study guide can be valuable in not only supporting but also in promoting self-learning. A study guide not only helps the students manage their learning but also allows teachers to plan the educational experiences and observe progress [3, 4]. It has been found to be effective with students at different levels of learning [5]. Students in an integrated curriculum found the study guide to aid day to day learning and further motivate active learning. Students perceived study guides to be beneficial because it helped them identify important concepts, compelled

*Corresponding Author: Muhammad Suleman Sadiq Hashmi, Lecturer III, Department of Health Professions Education, Liaquat National Hospital, Karachi,Pakistan; Email:drmuhammadsuleman@yahoo.com

Received: November 15, 2019; Revised: December 17, 2019; Accepted: December 20, 2019

DOI: https://doi.org/10.37184/lnjpc.2707-3521.1.8 them to read more regularly and helped them learn for assessments $[1,6]$.

Study guides can be produced in a wide variety of formats and layout but they should be composed of more than just the objectives list and course schedule [5, 7]. Study guides fall into three basic formats based on the functions they serve. These are: (a) the management of students' learning; guides aim to introduce the course, emphasize the expected learning outcomes and provide a structure for student learning (b) to provide a focus for students' activities related to their learning; major feature of these guides are activities that promote students' interaction with the course. The record of these activities can be used for formative or summative assessment (c) giving information about the course or topic: such guides are developed when teachers need to give additional information apart from that which is provided in lectures and resource material. In practice, most guides do not purely serve one function. They are usually a mix of these functions according to the students' needs [3]. Guides are now being developed both in print and electronic format [3]. Electronic study guides give students the added advantage to interact with the material and it can be personalized for individual requirements. Another benefit is immediate feedback can be given to students $[4,8,9]$.

Liaquat National Hospital and Medical College (LNHMC) follows an integrated modular curriculum. Study guides with consistent layout and format were designed for each module with the aim of providing students details 
about importance of the module and its placement, what they were required to learn, how much to learn and the sequence of study. Guidance was also given regarding the relevant resources available to achieve their learning outcomes. It also outlined the assessment process and methods. This study was conducted to assess the usefulness of these study guides in aiding student learning.

\section{METHODOLOGY}

This cross-sectional study was conducted at Liaquat National Medical College during December 2016 and January 2017. Survey population comprised of all second year MBBS students of LNHMC. A survey form was developed after 2 consecutive meetings among 3 medical educationists. It comprised of ten closed ended statements with a focus on the format of the study guide, the learning resources and assessment. A five point likert scale was used to score the form where $1=$ Strongly Disagree, 2 = Disagree, $3=$ Neutral, $4=$ Agree, $5=$ Strongly Agree. The form was kept anonymous.

The survey forms were distributed by the researchers to the students by hand at the end of the module exam of the Head and Neck module. They were collected immediately after the students had filled them. Data was analyzed using SPSS 18 (Table. 1). (response rate $80 \%$ ). About $38(47.5 \%$ ) of the students found the study guide easy to follow. 54(67.6\%) students found the study guide helpful in realizing the importance of the module being conducted. About $38(47.6 \%$ ) of students agreed to the usefulness of learning resources mentioned. About $68(85 \%)$ of students agreed that exam rules were clearly stated and almost $49(61.3 \%)$ felt that information on assessment tools was useful in preparing for the exams. Only $31(38.8 \%)$ of students believed that study guide supported learning.

\section{DISCUSSION}

This study assessed students' perception about the different aspects of the study guide i.e. format, importance of module, learning strategies, learning resources and assessment. The results showed that $48 \%$ of the students found the study guide easy to follow. Other studies demonstrate that students prefer study guides that are well-produced and attractive. Students also favor study guides that are user friendly $[6,10]$ and those that have a consistent layout [11]. Furthermore, size of the study guide is also a determinant of its effectiveness. Students find a pocket sized guide easier to carry and refer to during training [12].

Majority of the students agreed that the study guide is helpful in realizing the importance of the module

Table. 1: Students' perception of study guide.

\begin{tabular}{c|l|c|c|c|c|c}
\hline $\begin{array}{c}\text { S. } \\
\text { No. }\end{array}$ & \multicolumn{1}{|c|}{$\begin{array}{c}\text { Strongly } \\
\text { Disagree } \\
\text { Frequency (\%) }\end{array}$} & $\begin{array}{c}\text { Disagree } \\
\text { Frequency (\%) }\end{array}$ & $\begin{array}{c}\text { Neutral } \\
\text { Frequency (\%) }\end{array}$ & $\begin{array}{c}\text { Agree } \\
\text { Frequency (\%) }\end{array}$ & $\begin{array}{c}\text { Strongly } \\
\text { Agree } \\
\text { Frequency (\%) }\end{array}$ \\
\hline 1 & Study guide was easy to follow. & $4(5)$ & $9(11.3)$ & $29(36.3)$ & $32(40)$ & $6(7.5)$ \\
\hline 2 & $\begin{array}{l}\text { The introduction helped us realize the } \\
\text { importance of the module. }\end{array}$ & $1(1.3)$ & $3(3.8)$ & $22(27.5)$ & $41(51.3)$ & $13(16.3)$ \\
\hline 3 & $\begin{array}{l}\text { Learning objectives were clearly } \\
\text { stated. }\end{array}$ & $1(1.3)$ & $6(7.5)$ & $31(38.8)$ & $33(41.3)$ & $9(11.3)$ \\
\hline 4 & $\begin{array}{l}\text { Learning strategies identified in the } \\
\text { guide matched college schedule. }\end{array}$ & $2(2.5)$ & $6(7.5)$ & $26(32.5)$ & $36(45)$ & $10(12.5)$ \\
\hline 5 & $\begin{array}{l}\text { List of resources was helpful for self- } \\
\text { learning. }\end{array}$ & $2(2.5)$ & $6(7.5)$ & $34(42.5)$ & $27(33.8)$ & $11(13.8)$ \\
\hline 6 & $\begin{array}{l}\text { Links to external learning resources } \\
\text { were adequate for my learning needs. }\end{array}$ & $1(1.3)$ & $9(11.3)$ & $30(37.5)$ & $31(38.8)$ & $9(11.3)$ \\
\hline 7 & $\begin{array}{l}\text { Identified resource person made it } \\
\text { easy to seek guidance regarding my } \\
\text { concerns. }\end{array}$ & $2(2.5)$ & $3(3.8)$ & $29(36.3)$ & $37(46.3)$ & $9(11.3)$ \\
\hline 8 & $\begin{array}{l}\text { Information on the assessment tools } \\
\text { (BCQ, EMQ, OSPE) was useful in } \\
\text { preparing for exams. }\end{array}$ & $5(6.3)$ & $3(3.8)$ & $23(28.8)$ & $33(41.3)$ & $16(20)$ \\
\hline 9 & Examination rules were clearly stated. & $1(1.3)$ & $0(0)$ & $11(13.8)$ & $45(56.3)$ & $23(28.8)$ \\
\hline 10 & $\begin{array}{l}\text { Study guide did not support learning } \\
\text { for this module. }\end{array}$ & $7(8.8)$ & $24(30.0)$ & $21(26.3)$ & $20(25)$ & $8(10)$ \\
\hline
\end{tabular}

\section{RESULTS}

A total of 100 forms were distributed out of which 89 forms were returned. Only 80 forms were completely filled being conducted. Students are more willing to learn if the study guide demonstrates how the topic or module can contribute to their understanding of the course [2]. 
Students also opined that the learning objectives were outlined clearly. This is in concordance with other studies which showed that inclusion of objectives in study guide provide students focus of learning and result in increased productive time $[4,6,13]$. More than $50 \%$ students felt that it helped them identify learning strategies. This is in line with the results of studies that found guides helped them in identifying the teaching strategies like small and large group sessions and PBL [14].

Students were divided regarding the usefulness of resources mentioned. This response may be due to the individual study habits and less familiarity with self directed learning. List of resources is useful if particularly relevant items and cross references are highlighted [10]. Furthermore, it is more beneficial if some of the resource material is incorporated into the study guides themselves. For example Study Guides at St. Bartholomew's and the Royal London School of Medicine and Dentistry consist of lecture handouts [10].

A major benefit of the study guide found by students was in providing them information about assessment methods and process and helping them in preparing for examinations. This is an important component of a study guide as it motivates students to organize their learning keeping in mind the assessment [3]

Majority of the students felt that the identification of a resource person made it easy to seek guidance regarding their concerns. Students enter medical college from varied backgrounds. They may be hesitant to acknowledge difficulties and seek help. Hence it would be easier if students know who to approach in case of any difficulty or confusion [10].

Only a minor percentage of students believed that study guide supported learning. This is in contrast to other studies stating the worth attached by students to study guides as a learning aid $[6,14]$. One reason may be because of the format of the guide. Our guide was based on learning objectives. In the findings of one study, students perceived the learning outcomes to be useful, but the majority found this format of study guide was hard to use [14].

The limitations of the study were that only one cohort of students and a small portion of the curriculum was assessed.

\section{CONCLUSION AND RECOMMENDATIONS}

Study guides are an important component of the curriculum. Our study supports usefulness of study guide in areas like importance of module, learning objectives, strategies and assessment. Further more studies with other modules should be conducted. Awareness needs to be created among students on the proper use of study guides. We recommend that the improvement should be made as identified by this study. Future studies should be conducted to assess the impact of these improvements.

\section{CONFLICT OF INTEREST}

The authors declare no conflict of interest.

\section{ACKNOWLEDGEMENTS}

We are thankful to Prof. Nighat Huda for her continuous support and Dr. Sobia Ali for her guidance. We are also thankful to all the $2^{\text {nd }}$ year MBBS Students of LNHMC for their participation. Dr. Muhammad Suleman Sadiq Hashmi designed the study, collected and analyzed data, contributed to and reviewed the manuscript. Dr. Afifa Tabassum collected and analyzed data, contributed to and reviewed the manuscript.

\section{REFERENCES}

1. Ravichandran L. Student perception on study guides in an integrated preclinical curriculum. Sri Ramachandra J Med 2014; 7(2): $9-12$

2. Laidlaw JM, Harden RM. What is a study guide? Med Teach 1990; 12(1): 7-12.

3. Harden RM, Laidlaw JM, Hesketh EA. AMEE medical education guide no. 16: study guides-their use and preparation. Med Teach 1999; 21(3): 248-65.

4. Conderman G, Bresnahan V. Study guides to the rescue. Interv Sch Clin 2010; 45(3): 169-76.

5. Horton SV, Lovitt TC. Using study guides with three classifications of secondary students. J Spec Edu 1989; 22(4): 447-62.

6. Babar S, Baig L. Study guide usability survey: perception of students and teachers of an undergraduate medical college. J Pak Med Assoc 2014; 64(10): 1114-8.

7. Jenkins GA, Nepal K, Lemckert C. The use of study guides to improve learning outcomes in engineering fluid mechanics and hydraulics. In AAEE 2010: Past, Present, and Future. Proceedings of the $21^{\text {st }}$ Conference for the Australasian Association for Engineering Education. Sydney, New South Wales, 2010, 539-45.

8. Harden RM, Smyth JJ. Computer-based study guides II: educational components and advantages. Med Teach 1994; 16(4): 315-22.

9. Montemayor LL. Twelve tips for the development of electronic study guides. Med teach 2002; 24(5): 473-8.

10. Holsgrove GJ, Lanphear JH, Ledingham IM. Study guides: an essential student learning tool in an integrated curriculum. Med Teach 1998; 20(2): 99-103.

11. Al-Hazimi A. Development and evaluation of study guide template for an integrated cardiovascular module. Med teach 2012; 34(sup1): S6-13.

12. Mitchell E, Harden RM, Laidlaw JM. Towards effective on-the-job learning: the development of a pediatric training guide. Med Teach 1998; 20(2): 91-8

13. Begum S, Goud BM, Shetty JK, Zaki B, Sheelaharidas M. Development of study guide and student's perception about it as an essential tool in learning Biochemistry at RAK Medical \& Health Sciences University, Ras Al Khaimah. Int J Curr Res Med Sci 2016; 2(4): 16-21.

14. Khogali SE, Laidlaw JM, Harden RM. Study guides: a study of different formats. Med Teach 2006; 28(4): 375-7. 